\title{
Histological Study of Human Umbilical Cord in Diabetic Pregnant Females
}

\author{
Original \\ Mona Abd El-Rahman Salem, Shadia M Abd El-Gawwad, Eman S. Mahmoud \\ Article \\ and Heba Y. Elyamany
}

Departments of Histology and Cell Biology, Faculty of Medicine for Girls, Al-Azhar University, Cairo, Egypt

\begin{abstract}
Background: The umbilical cord (UC) is the lifeline between the fetus and placenta. It allows gas and nutrient exchange. Diabetes mellitus is the most common metabolic disorder that occurs during pregnancy, it has complications on both mother and fetus. The changes in the structure of UC with diabetes may have effect on the viability of the fetus.

Aim of the Work: Is to study the effect of gestational diabetes on the histological structure of UC.

Patients and Methods: The umbilical cord biopsies were collected immediately after delivery from 30 full term pregnant women, 15 normal pregnant females (Control group), and 15 pregnant women had gestational diabetes (Diabetic group). Informed written consent was taken from all pregnant women sharing in this study. These biopsies were processed for light and electron microscopic studies. Also morphometric and statistical analysis for the data were done.

Results: Light microscopic study of diabetic UC samples showed degeneration of Wharton's jelly fibers with formation of honey comb like empty spaces. Erosion of endothelial cells lined the umbilical vessels; with separation of their smooth muscle fibers were observed. There were degeneration of collagen fibers and decrease amount of elastic fibers in the wall of umbilical vessels. Morphometric studies showed significant decrease in the intima and media thickness in diabetic UC arteries compared to UC control arteries. The UC vein of diabetic samples showed significant dilatation of the lumen and thinner wall compared to that of control group.
\end{abstract}

Conclusion: The present study proved that gestational diabetes has many injurious effects on histological structure of UC.

Received: 29 January 2019, Accepted: 16 May 2019

Key Words: Gestational diabetes, UC, Histological structure, vascular changes.

Corresponding Author: Eman Said Mahmoud, MD, Departments of Histology and Cell Biology, Faculty of Medicine for Girls, Al-Azhar University, Cairo, Egypt, Tel.: +20 1002171324, E-mail: emansaid7374@gmail.com

ISSN: 1110-0559, Vol. 42, No. 4

\section{INTRODUCTION}

The umbilical cord (UC) is the linkage between the fetus and mother; it extends from fetal umbilicus to the fetal surface of the placenta. It functions throughout pregnancy to protect the vessels that travel between the fetus and the placenta which allow gas and nutrient exchange ${ }^{[1]}$. In human UC is dull white, moist, and covered by amnion, through which the umbilical vessels may be seen. The UC average diameter is 1 to $2 \mathrm{~cm}$ with average length is $55 \mathrm{~cm}$. The UC inserts at or near the center of the placenta in most pregnancies, in about $5-7 \%$ of the cases the insertion occurs at the maximum edge of the placenta (marginal insertion) and in about $1-2 \%$ of cases, the UC doesn't insert in the placenta at all, but the fetal vessels ramify through the external membranes before entering the placenta (velamentous insertion) ${ }^{[2]}$. The UC normally contains two umbilical arteries and one umbilical vein. These are embedded within a loose, gelatinous, proteoglycan rich matrix known as Wharton's jelly. A membrane called amnion holds the whole structures together ${ }^{[3]}$. The Wharton's jelly has physical properties much like a polyurethane pillow, is resistant to twisting and compression. This property serves to protect the critical vascular lifeline between the placenta and fetus ${ }^{[4]}$.

During pregnancy, the UC vein carries oxygen-rich blood and nutrients from the placental tissue to the fetus, while the arteries return poorly oxygenated blood and waste products as carbon dioxide to the placenta ${ }^{[3]}$. Human umbilical vessels differ from the major vessels of the same caliber in the body for many reasons. Transudation of fluid occurs in these vessels and they contribute in the formation of the amniotic fluid ${ }^{[5]}$.

Following delivery the cord quickly begins to dry out, harden and turn black, (dry gangrene), but the umbilical vessels remain patent for several days. At parturition the umbilical arteries retract into the abdomen and close by smooth muscle contraction. This process appears in response to the increased partial pressure of oxygen in the blood $^{[6]}$.

Diabetes mellitus is a group of metabolic diseases in which a person has high blood sugar, either because the pancreas does not produce enough insulin, or because cells do not respond to the insulin that is produced ${ }^{[7]}$. 
Gestational diabetes mellitus (GDM) is a common condition with risks for mother and fetus. GDM is defined as carbohydrate intolerance of variable severity with onset or first recognition during pregnancy ${ }^{[8]}$. It also considered as any degree of glucose intolerance starting or noticed during pregnancy. If the glucose tolerance is not noticed before pregnancy, we call it preexisting diabetes mellitus. The prevalence of pre-existing diabetes has increased in the past decade, primarily as a result of the increase in type 2 diabetes ${ }^{[9]}$.

The prevalence of GDM is debatable, because it is variable worldwide, depending on the population, human race and the diagnostic criteria defined by each country ${ }^{[10]}$. It is believed that this prevalence will increase because of the growth of risk factors including advanced maternal age, obesity and lifestyle ${ }^{[11]}$, also females using corticosteroid medication ${ }^{[12]}$ or pregnant having gestational diabetes in a previous pregnancy or pre diabetics are considered also as high risk groups ${ }^{[13]}$.

International Diabetes Federation estimates that 16\% of the children born alive in 2013 all around the world had complications due to hyperglycemia during pregnancy ${ }^{[14]}$.

Gestational diabetes mellitus (GDM) is a multifactorial disorder resulting from genetic and environmental interactions. Insulin resistance and impaired $\beta$-cell function both contribute to GDM. Pregnancy is a diabetogenic state characterized by impaired insulin sensitivity; this is particularly noted in 2nd trimester of pregnancy. The major contributors are the placental hormones namely, human placental lactogen, progesterone, cortisol, growth hormone and prolactin. These hormones cause decreased phosphorylation of insulin receptor substrate -1 and thus profound insulin resistance ${ }^{[15]}$.

Complications related to the GDM affect both maternal and fetal health and thereafter child health. Women who have had GDM have a significant higher risk to develop type 2 diabetes mellitus ${ }^{[11]}$. Cardiovascular complications include chronic hypertension, pregnancy-induced hypertension, and, rarely, atherosclerotic heart disease ${ }^{[16]}$. Neonatal macrosomia, shoulder dystocia, hypoglycemia, hyperbilirubinemia, birth trauma and respiratory distress are the most common fetal complication ${ }^{[17]}$.

Since the umbilical cord acts as a communicating channel between the uterine vasculature and the fetal vasculature, so any condition make any change in the uteroplacental vascular tree as GDM should have an effect on the umbilical vessels and fetal wellbeing ${ }^{[18]}$.

\section{PATIENTS AND METHODS}

Thirty pregnant women with full term (37- 40 wks.) gestation with age ranging from (25-35) years old having single pregnancy coming for delivery (normal or caesarian sections) at Obstetrics and Gynecology Department, Al Zhraa University Hospital were used during period from October 2017 till March 2018.
All other abnormal conditions during pregnancy such as smoking, corticosteroid therapy, pre-eclampsia and pregnancy induced hypertension were excluded. These females were divided in two groups: Control group (normal blood glucose levels) and Diabetic group (pregnant has GDM). Written informed consent was obtained from all mothers in accordance with the Research Ethical Committee (REC).

After delivery the UC tissue samples were immediately collected from side of newly born infant $2 \mathrm{~cm}$ from umbilical stump, and were put in fixative $10 \%$ formalin for light microscopic examination. Six samples were cut into one cubic millimeter $(1 \mathrm{~mm} 3)$ and fixed in glutaraldehyde for electron microscopic examination.

\section{1- Light microscopic examination}

Specimens of UC were fixed by immersion in $10 \%$ neutral buffer formalin, for 2 days at room temperature. Dehydration was done in ascending grades of ethyl alcohol. The specimens were then cleared in a benzene for 30 minutes. They were infiltrated in molten paraffin, sectioned with the rotatory microtome at $5 \mu \mathrm{m}$ thickness then mounted on a clean glass slide and stained with Hematoxylin and Eosin (HandE) for routine histological examination, Mallory's trichrome stains for the collagen fibers $^{[19]}$, Orcein stain for elastic fibers and Periodic Acid Schiff (PAS) stain (deep red color) for; carbohydrates (glycogen), reticular fibers (i.e. collagen) in connective tissue, and basement membrane ${ }^{[20]}$.

\section{2- Electron microscopic technique}

Specimens of UC were trimmed and fixed in 5\% glutaraldehyde, for 4-24 hours, and then processed according to Robinsons et al. ${ }^{[21]}$. The ultrathin sections were examined and photographed by (JEOL 100S Tokyo, Japan) transmission electron microscope.

\section{3- Morphometric and statistical studies}

Morphometric measurements were carried out using a computerized image system composed of a Leica Quin 500 image analyzer which is connected to a Leica microscope. It is used for measurement of collagen area percentage in the wall of umbilical artery and vein in Mallory's trichrome stained sections. Measurement of the wall thickness of the artery (intima and media) and vein (whole thickness) were done. Optical density of PAS stained sections was measured by using the NIH Image J (v1.50) program. Optical density was calculated by the following formula:

Optical density $=\log (\max$ intensity/mean intensity $)$, where $\max$ intensity $=255$ for 8 -bit images ${ }^{[22]}$. Mean value and standard deviation were obtained from each specimen, for statistical analysis using the statistical software "Statistica for Windows" Version 5. The statistical analysis was performed using the mean value $(\mathrm{M})$ and standard deviation (S.D) according to Mould, 1989 ${ }^{[23]}$. Statistical analysis was estimated by student $(\mathrm{t})$ test. Results were considered significant when probability $(p)$ was $\leq 0.05$. 


\section{RESULTS}

\section{Light microscope}

Light microscopic examination of UC of control group sections stained with HandE showed that they were composed of two arteries and one vein embedded in mucoid connective tissue (Wharton's jelly) and enclosed by amniotic membrane formed of single layer of cubical epithelium. Wharton's jelly was composed of branched basophilic fibroblast cells with central large nuclei and mucoid matrix. The normal cord artery showed star shaped lumen, its intima was formed of simple squamous endothelial cells and well-developed sub-endothelial connective tissue with no internal elastic lamina. The media was thick and formed of irregularly arranged smooth muscle cells (SMC) with spindle shaped appearance and central oval nuclei and acidophilic cytoplasm. The fibers separated by connective tissue with variable amounts of elastic and collagen fibers and ground substance. The adventitia in the arteries was replaced by condensation of surrounding mucoid connective tissue. The UC vein was characterized by wider lumen and thinner wall compared to the artery. It was composed of thin intima and media, also the adventitia was replaced by condensation of surrounding mucoid connective tissue (Figure 1).

Light microscopic examination of UC of diabetic group sections stained with HandE revealed that Wharton's jelly showed disruption of its fibers which became widely separated by large irregular empty spaces like honey combs. The arteries showed more constricted lumen in comparison to control group. The endothelial cells of the intima were discontinuous with focal erosions. The media showed widely separated SMC by C.T containing few collagen and elastic fibers with mononuclear cell infiltration. Extravasation of arterial blood to Wharton's jelly was seen. The vein was characterized by thinner wall and wider lumen in comparison to the control group. Also there was no adventitia (Figure 2).

Light microscopic examination of UC of control group sections stained with Mallory trichrome showed collagen fibers within Wharton's jelly. The arterial wall contained more collagen fibers in intima and in-between SMC of media compared to the vein wall. The fibers in both vessels run longitudinally in intima and circularly between SMC of the media. Umbilical cord sections of diabetic groups stained with Mallory stain showed decreased collagen fibers which were separated by wide empty spaces. The arteries and veins showed disruption and degeneration of collagen fibers in intima and in between SMC of the media with decrease amount of collagen fibers, and disorientation of their arrangement in intima and media (Figure 3).

Light microscopic examination of UC of control group sections stained with orcein stain showed that the umbilical arteries were rich in elastic fibers which run longitudinally in the intima with lacked internal elastic lamina. The media contained few elastic fibers which run circularly between the SMC. The umbilical vein contained fewer amounts of elastic fibers in comparison to the artery with prominent interrupted internal elastic lamina. The same orientation of elastic fibers in intima longitudinally and media circularly similar to that of the artery was observed. Umbilical cord sections of diabetic groups stained with orcein stain showed decreased amount of elastic fibers in intima and media of the umbilical arteries and vein with loss of their arrangement and destruction in some areas (Figure 4).

Umbilical cord sections stained with PAS showed nonsignificant increase in PAS +ve reaction (glycogen content) of diabetic groups in intima and media of both artery and vein compared to control group (Figure 5)

\section{Results of electron microscopic examination}

Electron microscopic examination of UC of control group showed that; Wharton's jelly was composed of branched fibroblast cells with large oval central nuclei, surrounded by irregularly arranged collagen fibers and reticular fibers. The cells were embedded in homogenous masses of mucoid matrix (Figure 6).

Umbilical artery was composed of the intima; single layer of endothelial cells with flat nuclei and welldeveloped sub-endothelial C.T. The endothelial cells had mitochondria, primary, secondary lysosomes and rough endoplasmic reticulum with intercellular digitation.

The media was composed of irregularly arranged layers of SMC with its spindle shaped appearance and central large nuclei with prominent nucleolus and irregular electron dense bodies in their cytoplasm. The cytoplasm of the myocytes showed myofibril, mitochondria, ribosomes, lysosomes, Golgi bodies and centrioles appeared in the centrosome. The muscle fibers are separated by C.T containing collagen and elastic fibers (Figure 7).

The UC vein had thinner wall than that of the artery with intima consisted of a single layer of endothelial cell, sub endothelial C.T and incomplete internal elastic lamina. The media consisted of irregularly arranged spindle shaped SMC with central large oval nuclei. The muscle fibers are separated by C.T containing collagen fibers and less elastic fibers (Figure 8).

Electron microscopic examination of UC of diabetic group showed that; Wharton's jelly with fibroblast cells which were separated by honey combs like empty spaces of mucoid matrix and decrease in collagen fibers. The arterial wall showed constricted lumen with many blood cells inside it. The intima showed separation of endothelial lining. The media showed wide separation of smooth muscle fibers by C.T containing small amount of irregularly arranged collagen fibers and reticular fibers. The UC vein showed erosion and degeneration of its lining endothelium. The smooth muscle fibers widely separated by C.T containing small amount of irregularly arranged collagen fibers (Figure 9). 


\section{Morphometric Results}

\section{1-Measurement of collagen area percentage in the wall of umbilical artery and vein}

Image analysis revealed that there was statistically significant decrease in the collagen area percentage in the wall of umbilical artery and vein for diabetic group compared to control group (Table 1 and Histogram 1).

\section{2- Measurement of thickness of the UC artery wall ( $\mu \mathrm{m})$ of control and diabetic groups}

Image analysis of the present data revealed that there was statistically significant increase in mean value of both intima, and media thickness for diabetic group compared to the control group as show in (Table 2 and Histogram 2).

\section{3- Measurement of the UC vein wall thickness ( $\mu \mathrm{m})$} and lumen diameter of control and diabetic groups

Image analysis revealed statistically significant decrease in vein wall thickness of diabetic group compared to control group. Also there was statistical significant increase in the vein lumen diameter in diabetic group compared to control group (Table 3 and Histogram 3).

4- Measurement of the optical density of PAS positivity in the wall of artery and veins of $U C$ sections from control and diabetic groups

Image analysis revealed non statistically significant increase in the PAS with mean value were $(0.935)$ for artery and (1.203) for vein walls in diabetic group compared to control group where the mean value were (1.097) for artery, and (1.293) for vein wall, with $p$ value $<0.02$ (Histogram 4).

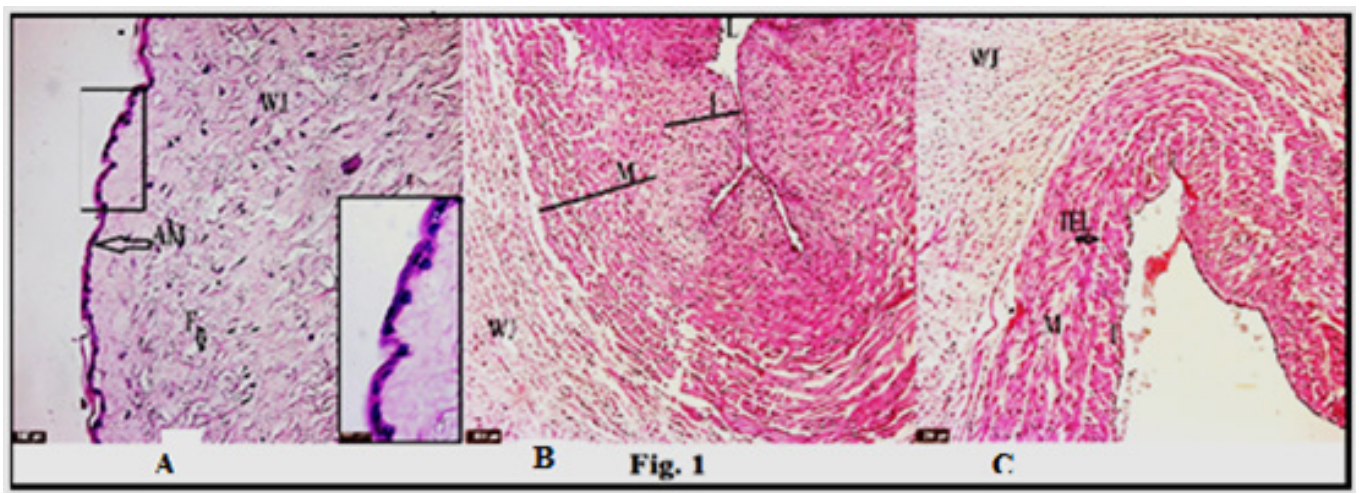

Fig. 1: Photomicrographs of UC sections of control group showing: (A) Wharton's jelly (WJ), fibroblast cells (F) and enclosed by amniotic membrane (arrow). The inset is higher magnification of the amniotic membrane. (B): showing part of umbilical artery with lumen (L), intima (I) and thick media (M) with no adventitia, surrounded by Wharton's jelly (WJ). (C) Showing the umbilical vein with wide lumen (L), thin intima (I) and thin media (M), and surrounded by Wharton's jelly (WJ). (HandE X 200,400 - 100 - 100).

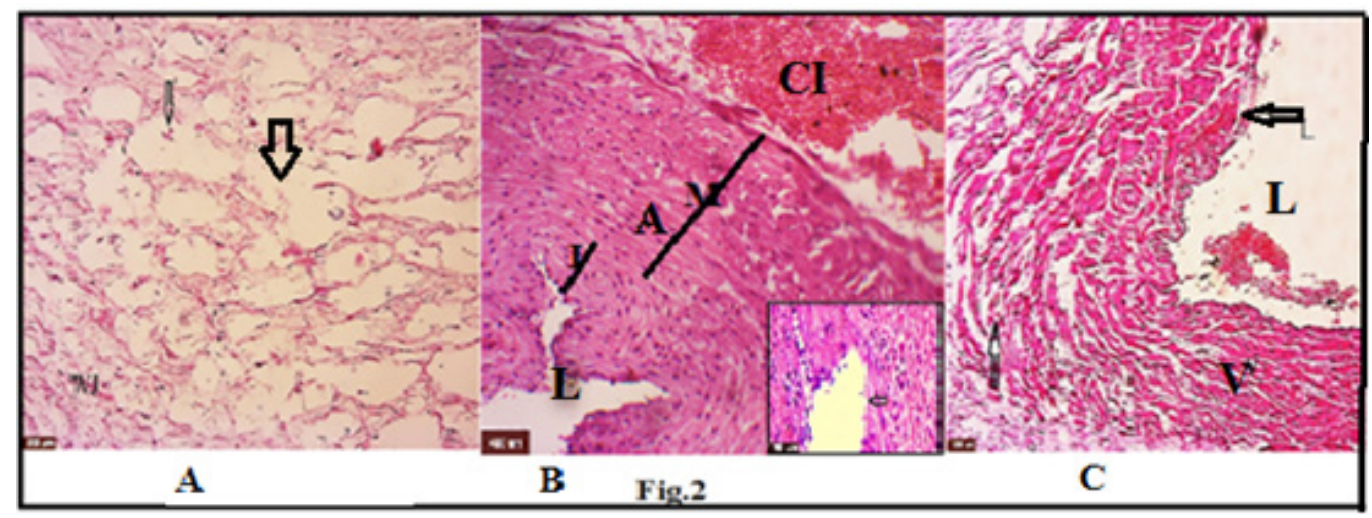

Fig. 2: Photomicrographs of UC sections of diabetic group showing: (A) Wharton's jelly (WJ), notice honey combs ( $\downarrow$ ) (B): showing part of umbilical artery (A) with narrow lumen (L), intima (I) and thick media with cellular debris (M), with extra cellular infiltration (CI), focal erosion of endothelial lining ( $\downarrow$ )(seen in inset $(\leftarrow)(\mathrm{C})$ Showing the wall of umbilical vein $(\mathrm{V})$ with thinner wall and wider lumen (L), with cellular debris in media (HandE X 100- 50, 200 -100). 


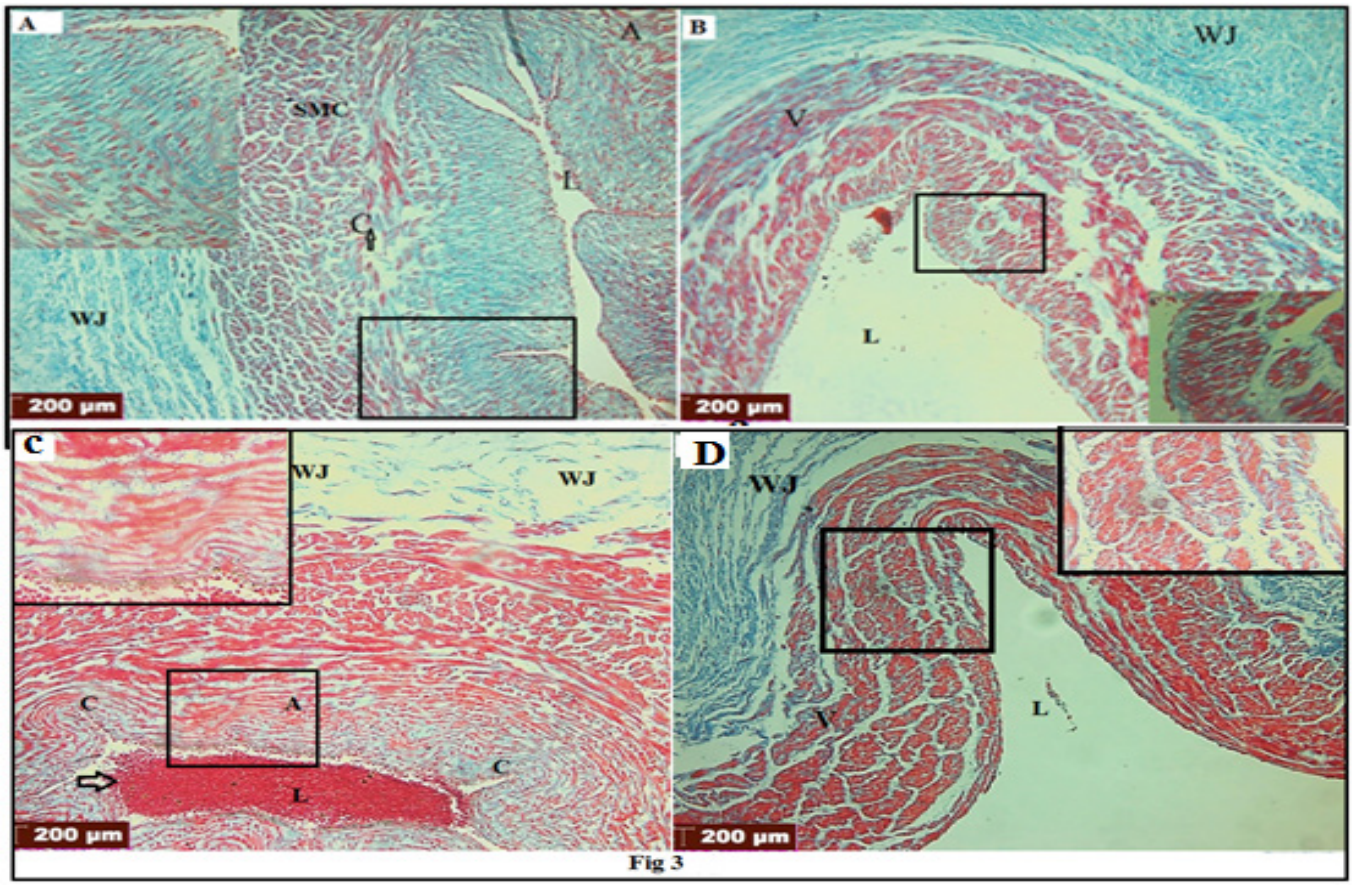

Fig. 3: The images shows (A) Wharton's jelly (WJ), collagen fibers (blue) and part of umbilical artery with narrow lumen (L) collagen fibers (c) in intima and in-between SMC of media (The inset is higher magnification of rectangular selected to show collagen fibers run longitudinally in intima and circularly between SMC in media).(B): Showing the wall of umbilical vein (V) with collagen fibers in intima and in-between SMC of media(The inset is higher magnification of rectangular selection to show collagen fibers run longitudinally in intima and circularly between SMC in media) (C) Wharton's jelly (WJ) of diabetic group with few collagen fibers and part of umbilical artery (A) with narrow lumen (L) filled with blood $(\rightarrow)$,and marked decrease in collagen fibers (C)in intima and media (The inset is higher magnification of rectangular selected to show collagen fibers which irregularly arranged in intima and media).(D): Showing the wall of umbilical vein of diabetic group with decreased amount of collagen fibers (The inset is higher magnification of rectangular selected to show collagen fibers which irregularly arranged in intima and media (Mallory trichrome X 100- 200-100and200).

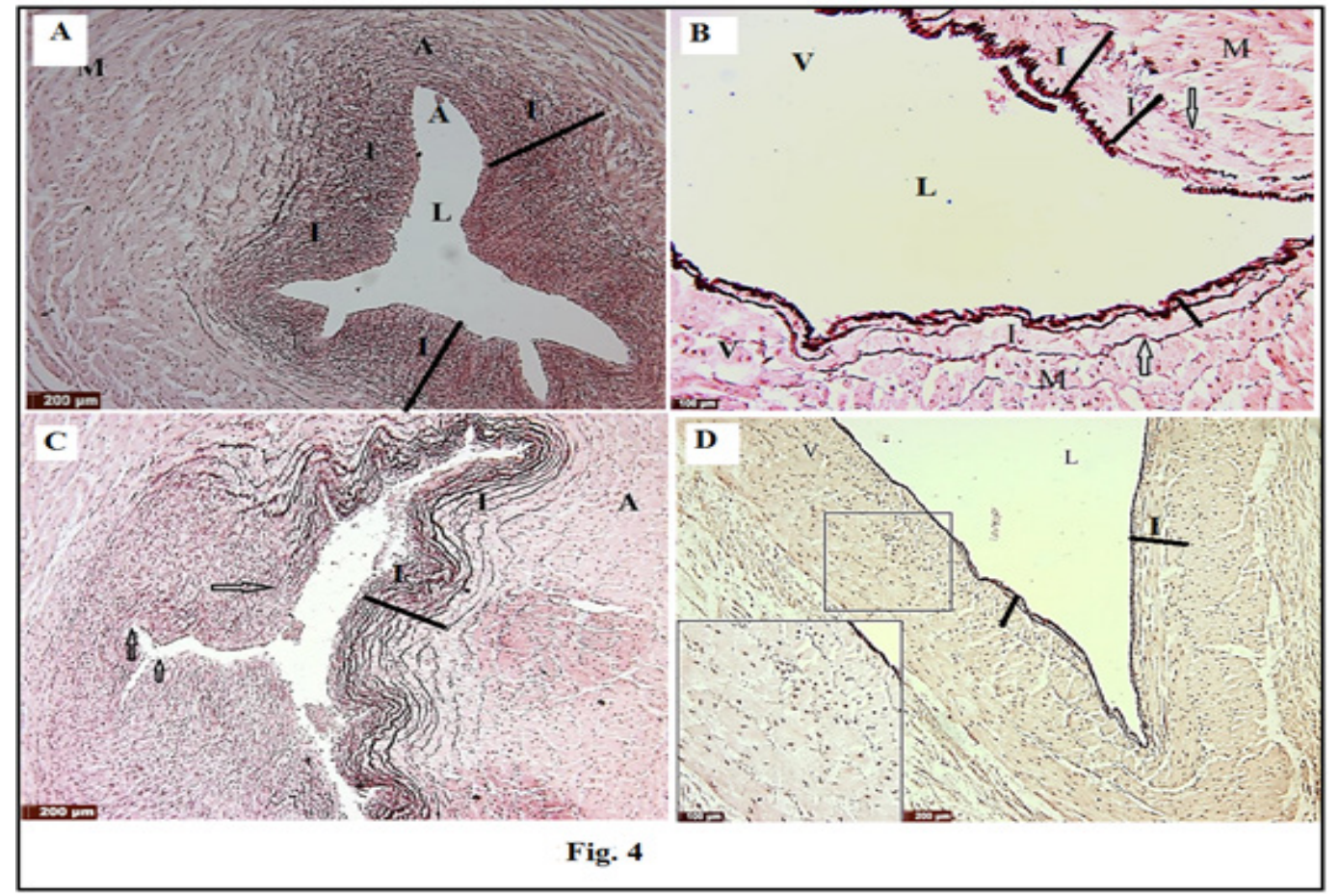

Fig. 4: The images show: (A) umbilical artery (A) of control group lumen (L). The elastic fibers in intima run longitudinally, no internal elastic lamina. The elastic fibers in media run circularly between smooth muscle cells (B): Umbilical vein (V) and its dilated lumen (L). The wall of vein show well defined internal elastic lamina $(\uparrow)$ and fewer elastic fibers compared to the artery. (C) umbilical artery (A) of diabetic group showing: with elastic fibers in intima (I) decrease in some areas $(\rightarrow)$ with disorientation of their arrangement in intima and media (D): umbilical vein (V) with decrease in the amount of elastic fibers in intima and media. There is loss of their arrangement and absence of internal elastic lamina (Orcein X $100-200-100$ and 200). 


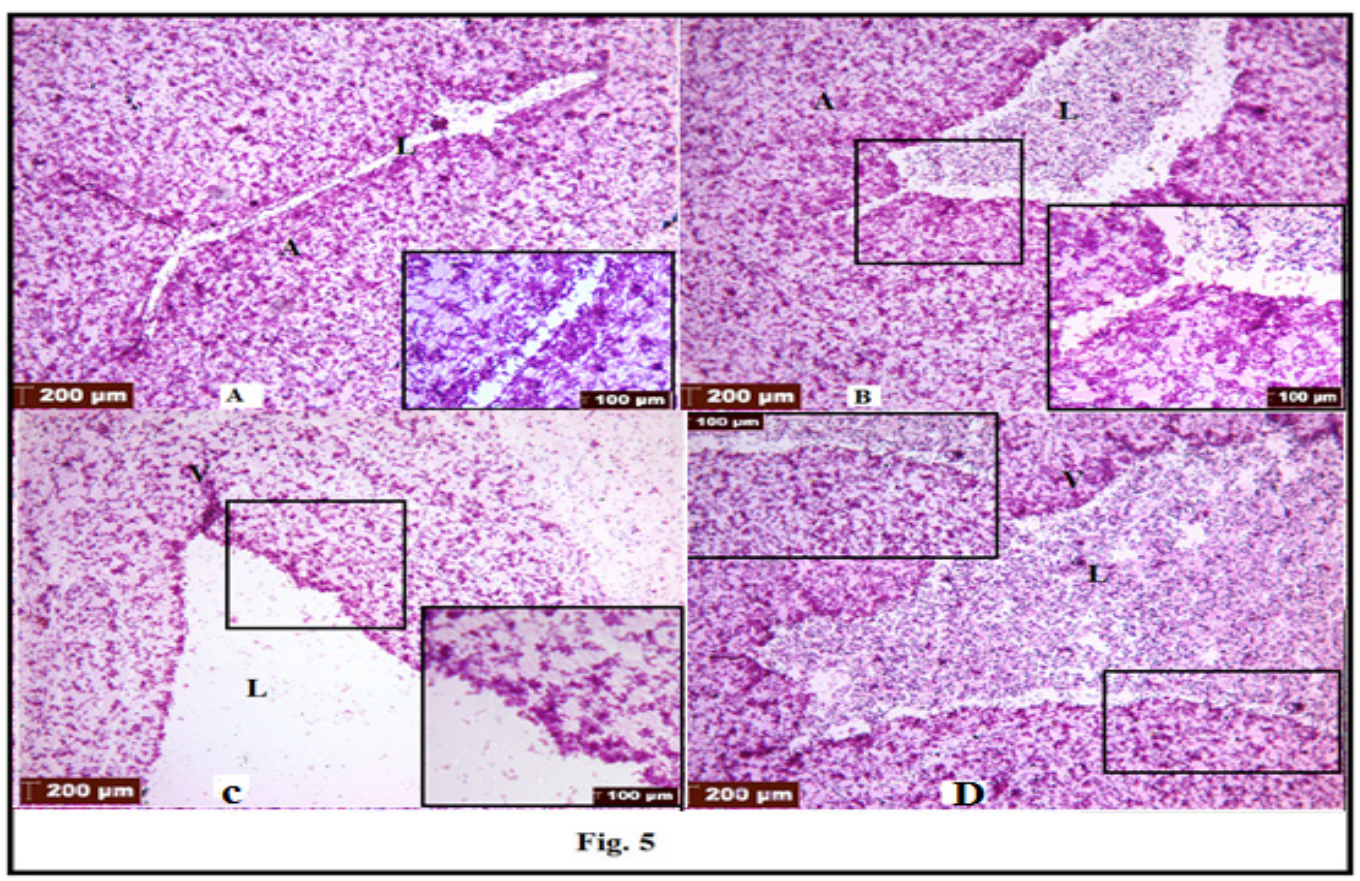

Fig. 5: The images show (A) umbilical artery of control group showing lumen (L). +ve PAS reaction is seen in intima and media. (B): the umbilical artery of diabetic group (A) with its lumen (L). Mild increase in PAS +ve reaction is seen in intima and media compared to (A). (C) umbilical vein (V) of control group with its lumen (L). + ve PAS reaction is seen in intima and media. (D): umbilical vein (V) of diabetic group with lumen (L). Mild increase in PAS +ve reaction is seen in intima and media compared to (C) (PAS X 100-200-100and 200 respectively). Note inset is higher magnification in parts in rectangles.

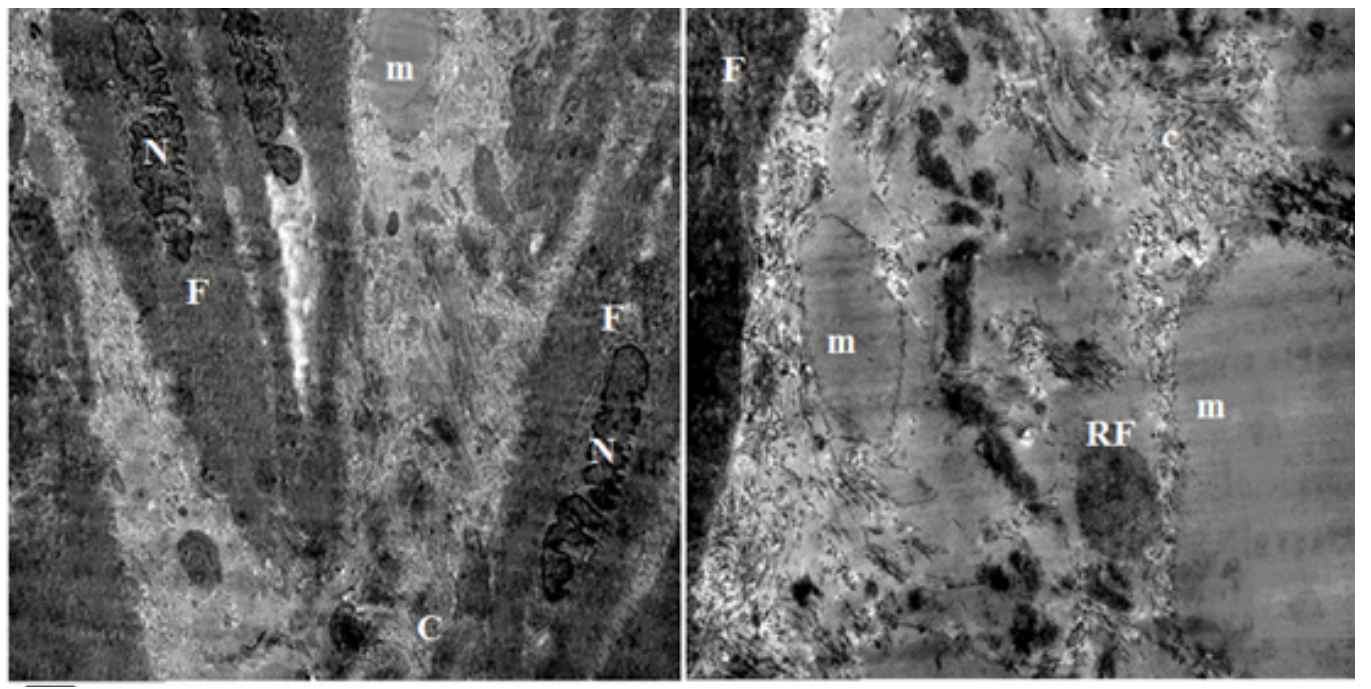

Fig 6: Electron micrograph of parts of UC of control group showing: (A): Wharton's jelly, fibroblast cell (F) with central large oval nucleus (N), separated by collagen fibers (c) and reticular fibers (B): part of fibroblast (F) collagen fibers (c), reticular fibers (RF) and homogenous masses of mucoid matrix (m). (Uranyl acetate and Lead citrate X5000-10000). 

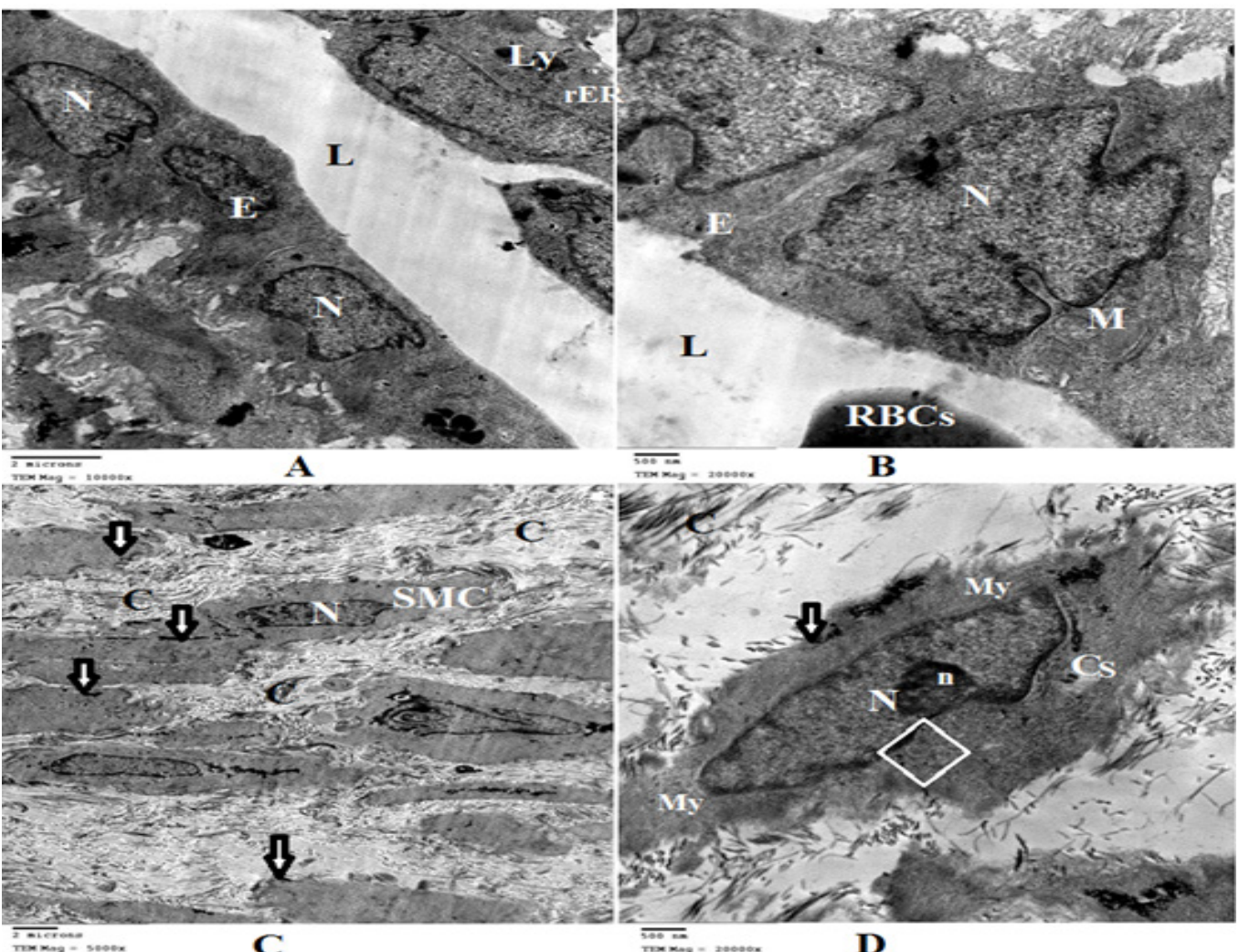

Fig. 7

Fig 7: Electron micrograph of parts of UC artery of control group showing a: (A): lumen (L) and lining endothelium (E) with central flat nuclei (N), lysosomes (Ly), and rough endoplasmic reticulum (rER). (B): arterial lumen (L) with part of red blood cell in lower part (RBC) and endothelial cell (E) with central oval nucleus $(\mathrm{N})$ and mitochondria $(\mathrm{M})$ and rough endoplasmic reticulum (rER). (C): with irregularly arranged (SMC) which are spindle shaped with central large oval nucleus (N), and dense bodies (arrows) and separated by connective tissue containing collagen (c). (D): (SMC) with central large nucleus (N) with prominent nucleolus (n), mitochondria (shape), dense bodies (arrows), myofibrils (My) and centrioles that appeared in the centrosome (cs) (Uranyl acetate and Lead citrate X 10000- 20000- 5000 - 20000 respectively).

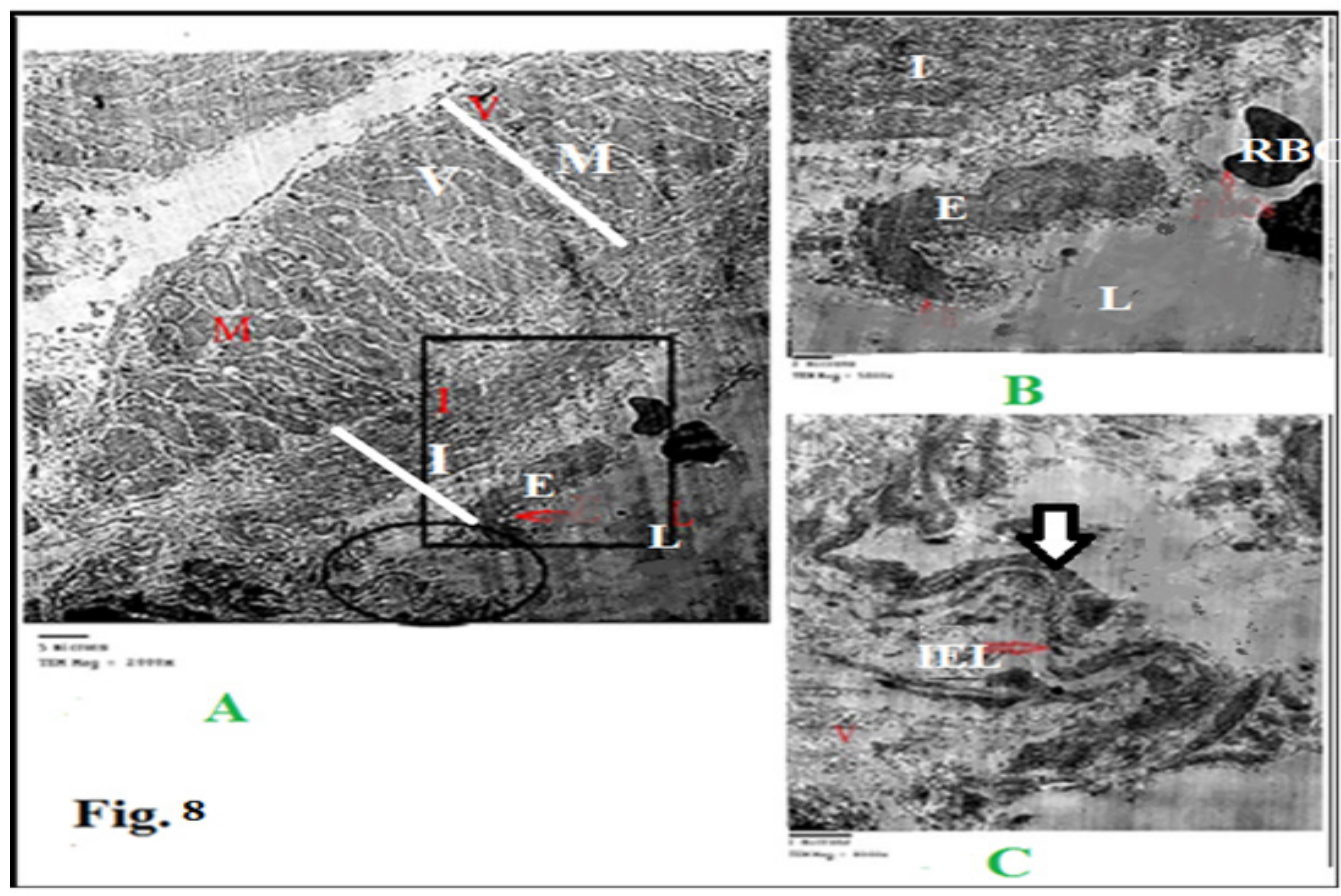

Fig. 8: Electron micrograph of UC sections of control group showing: (A) umbilical vein, lumen (L). The vein lined by endothelium (E), notice thin intima (I) and media (M) (B): Higher magnifications of rectangular part to show umbilical vein lumen (L) containing red blood cells (RBCs) and the intima of umbilical vein with its lining simple squamous epithelium (endothelium) (E) (C) Higher magnifications of circular part of to show incomplete internal elastic lamina "IEL" (arrow). (Uranyl acetate and Lead citrate X 2000 - 5000 - 8000 respectively). 


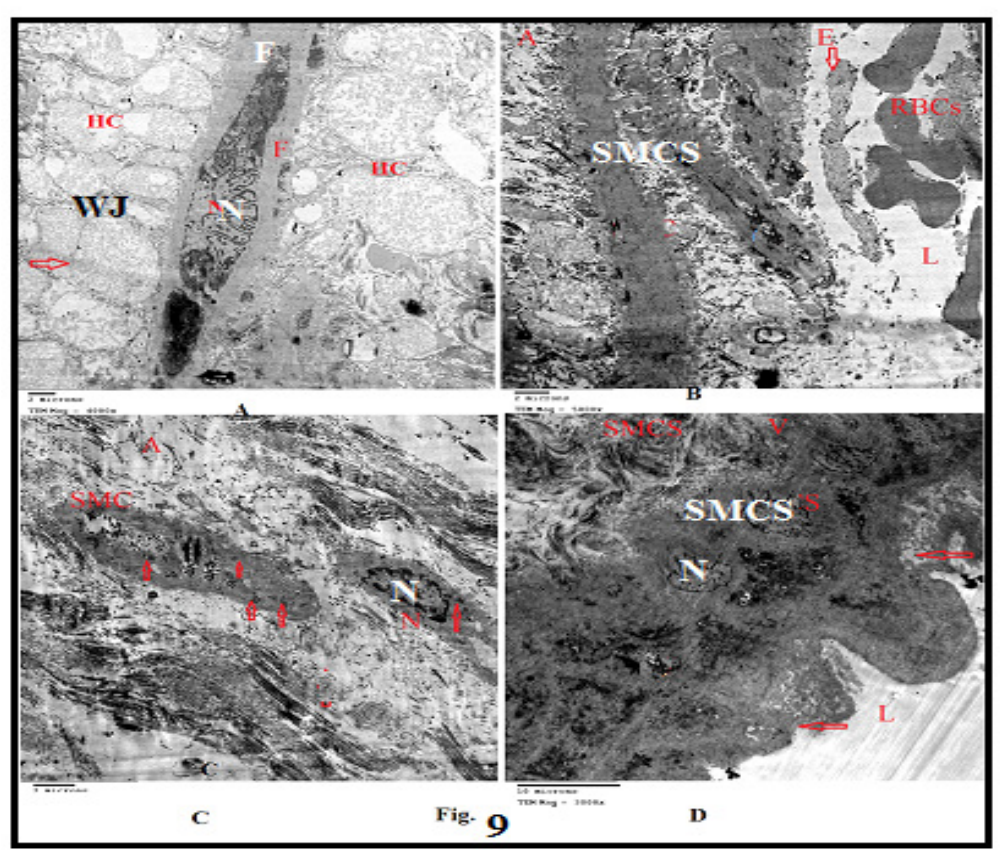

Fig. 9: Electron micrograph of parts of UC of diabetic group showing a: (A): honey combs $(\rightarrow)(\mathrm{HC})$ Wharton's jelly (WJ), with fibroblast cell (F). (B): arterial lumen (L) with more red blood cell (RBC) and separated endothelial cell (E). (SMC), separated by C.T containing small amount of collagen fibers. (C): with irregularly arranged (SMC) which are spindle shaped with nucleus (N), and dense bodies (arrows) and separated by connective tissue with few collagen fibers (c). (D): wall of UC vein (V), its lumen (L). Eroded endothelium ( $\leftarrow$ ) and SMCs (Uranyl acetate and Lead citrate X 4000- 5000- 6000 - 3000 respectively).

Table 1: Collagen area percentage in the wall of umbilical artery and vein of the control and the diabetic groups.

\begin{tabular}{|c|c|c|c|c|c|}
\hline Item & Groups & $\begin{array}{c}\text { Control } \\
\text { Mean } \pm \text { SD }\end{array}$ & $\begin{array}{c}\text { Diabetic } \\
\text { Mean } \pm \text { SD }\end{array}$ & t Test & $P$ value \\
\hline & Collagen area percentage of artery & $44.52 \pm 5.283$ & $26.14 \pm 6.725$ & 4.806 & 0.001 \\
\hline & Collagen area percentage of vein & $23.72 \pm 6.341$ & $13.32 \pm 2.188$ & 3.469 & 0.008 \\
\hline
\end{tabular}

$\mathrm{t}$ - Test is a test for comparison between two groups, $p \leq 0.05$ statistically significant.

Table 2: Intima and media thickness $(\mu \mathrm{m})$ in the umbilical cord of control and diabetic groups.

\begin{tabular}{|c|c|c|c|c|c|}
\hline Item & Groups & $\begin{array}{c}\text { Control } \\
\text { Mean } \pm \text { SD }\end{array}$ & $\begin{array}{c}\text { Diabetic } \\
\text { Mean } \pm \text { SD }\end{array}$ & $\mathrm{t}$ Test & $P$ value \\
\hline & Intimal thickness & $205.63 \pm 17.630$ & $299.14 \pm 40.185$ & 4.765 & 0.001 \\
\hline & Media thickness & $323.93 \pm 103.614$ & $832.53 \pm 98.605$ & 7.951 & 0.001 \\
\hline
\end{tabular}

$\mathrm{t}$ - Test is a test for comparison between two groups, $p \leq 0.05$ statistically significant.

Table 3: Vein wall thickness $(\mu \mathrm{m})$ and lumen diameter $(\mu \mathrm{m})$ in the umbilical cord of control and diabetic groups.

\begin{tabular}{|c|c|c|c|c|c|}
\hline Item & Groups & $\begin{array}{c}\text { Control } \\
\text { Mean } \pm \text { SD }\end{array}$ & $\begin{array}{c}\text { Diabetic } \\
\text { Mean } \pm \text { SD }\end{array}$ & t Test & $P$ value \\
\hline & Vein thickness & $832.24 \pm 114.067$ & $533.38 \pm 78.380$ & 4.828 & 0.001 \\
\hline & vein lumen width & $256.97 \pm 28.096$ & $348.35 \pm 19.08$ & 8.5 & 0.001 \\
\hline
\end{tabular}

$\mathrm{t}$ - Test is a test for comparison between two groups, $p \leq 0.05$ statistically significant. 


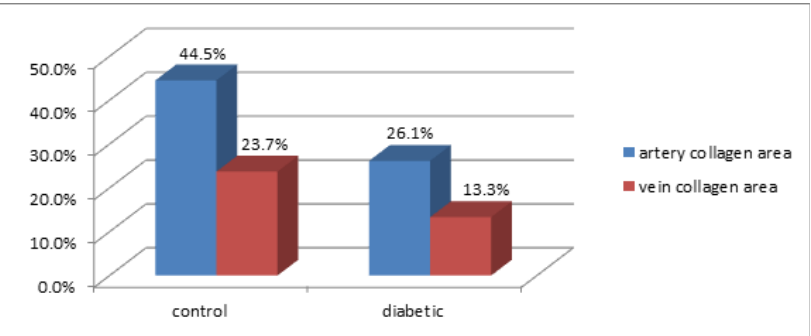

Histogram 1: Collagen area percentage in wall of umbilical artery and vein of the control and the diabetic groups.

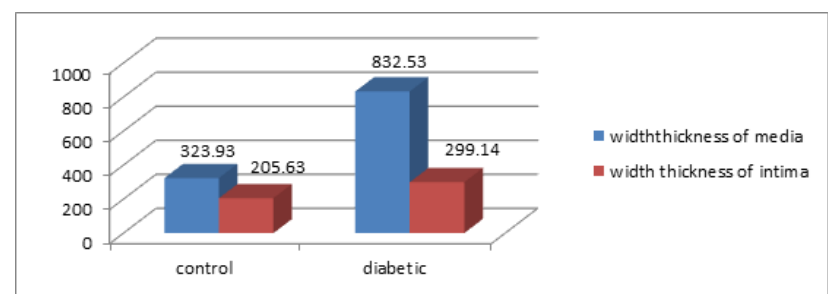

Histogram 2: Intima and media thickness $(\mu \mathrm{m})$ in the umbilical cord of control and diabetic groups.

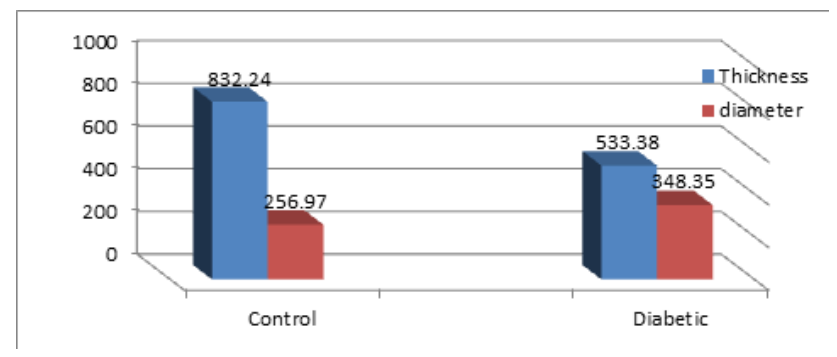

Histogram 3: Vein thickness $(\mu \mathrm{m})$, and lumen width $(\mu \mathrm{m})$ in the umbilical cord of control and diabetic groups.

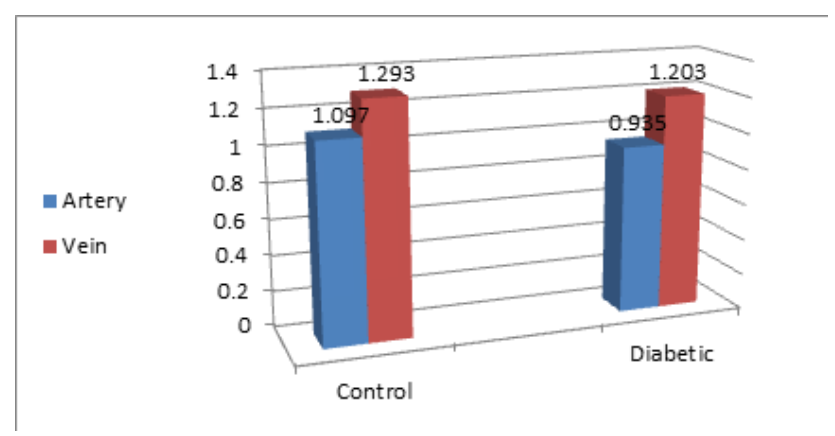

Histogram 4: Comparison between the optical density of PAS positivity in wall of artery and vein of controls and diabetic group.

\section{DISCUSSION}

The umbilical cord provides communication between the placenta and the fetus and allows gas and nutrient exchange ${ }^{[24]}$.

Gestational diabetes mellitus (GDM) is defined as any degree of glucose intolerance starting with pregnancy or noticed during pregnancy ${ }^{[11]}$.

The present study was planned to study the structure of umbilical cord in full term uncomplicated human pregnancy and in pregnancy complicated with diabetes using light and transmission electron microscopy.

The offspring of women with GDM are at increased risk of macrosomia, neonatal hypoglycemia, hyperbilirubinemia, shoulder dystocia, and birth trauma. There is also an increased risk of stillbirth, so samples were collected from umbilical cord near the new born as it is the nearest part to the newborn which mostly has effect on its viability and to fix the part of study.

Examination of diabetic samples in the current study showed disruption and degeneration of collagen fibers of Wharton's jelly which markedly decreased in amount and become widely separated by large irregular empty spaces like honey combs. These degeneration and empty spaces may represent patches of ischemic infarction due to impaired umbilical cord blood flow resulting from the constricted lumen and arterial changes associated with diabetes.

Also degeneration Wharton's jelly may be due to migration of stem cells which normally controlled by hyaluronic acid of Wharton's jelly ${ }^{[25]}$.

This result coincide with the results of Charkraborty et al., ${ }^{[26]}$ who looked for the microscopic impacts of GDM on umbilical cord using human samples of umbilical cord and placenta. They stated that there was alteration in the pattern and distribution with degeneration of fibers of Wharton's jelly with honeycombs like empty spaces among them.

Koskinen et al., ${ }^{[27]}$ reported that maternal diabetes induces alterations in the ultrastructure of human umbilical cord of newborn infants. These changes include defects in extracellular matrix, vessel wall modeling, decrease of the collagen fibers and edema.

In the present study, the diabetic umbilical arteries showed focal discontinuation and destruction of the lining endothelium, these changes may be due to inflammation that occurs because of hyperglycemic stress. That result is in agreement with Di Fulvio et al., (2014) ${ }^{[28]}$, who reported that endothelial cells exposed in vivo even transiently to hyperglycemia, oxidative stress and inflammation exhibit durable pro-atherogenic modifications.

Vas et al., ${ }^{[29]}$ found areas of ulceration and desquamation of the endothelial surface with platelets were seen to be adhered and aggregated to the area of endothelial damage in the peripheral arteries of diabetic patients.

Occasionally rupture of umbilical artery occurred with extravasation of blood, and increased cellular debris within Wharton's jelly and in between SMC of the media due to hydrobic degeneration of muscle fibers. These finding agreed with Salem et al., ${ }^{[30]}$ who found that areas of hemorrhage and red blood cells were found free in the wall of the peripheral arteries of diabetic patients. Alam et al., ${ }^{[31]}$ also found rupture and erosions of endothelial lining of umbilical arteries resulting in increased permeability of the vessels in diabetes. 
Increased intimal thickness in diabetics UC samples may be due to neointimal hyperplasia which recorded in normal physiology and in pathophysiological as vascular occlusive states occur as the result of chronic exposure to pathological levels of shear stress ${ }^{[25]}$.

The umbilical arteries also showed wide separation of SMC of the media by C.T containing irregularly arranged collagen fibers and elastic fibers.

Similar results reported by Charkraborty et al., ${ }^{[26]}$ who said that in light microscopy of UC samples in GDM showed rupture and erosion of endothelium and complete rupture of the umbilical vessels resulting in extravasation of blood within Wharton's jelly, also SMC of umbilical vessel showed disruption and degeneration of their fibers.

The present study revealed that there was an increase in the thickness of both intima and media layers of umbilical artery of diabetic group. That agreed with Sarikabadayi et al., ${ }^{[32]}$ who found among the infants of GD mothers, macrosomia appeared as a result of increased the thickness of umbilical artery intima-media layer.

Salem et al., ${ }^{[30]}$ reported that narrowing of the lumen and thickening of the wall were more common vascular complications in diabetes. In spite of their study was on peripheral arteries not on umbilical arteries, but they agreed with the present study in this point.

The current light microscopic study of diabetic group showed that there were increase in the diameter of the vein lumen [dilatation] and decrease in its wall thickness if compared to the control group that agreed with Alam et al. ${ }^{[31]}$ who said that umbilical vessels have a tendency for dilatation and thinness in diabetic condition and showed rupture and erosions of endothelial lining of umbilical arteries resulting in increased permeability of the vessels in diabetes.

Charkraborty et al., ${ }^{[26]}$ who looked for the microscopic impacts of GDM on umbilical cord using human samples of umbilical cord and placenta also mentioned that the umbilical vein was unduly dilated and thin walled. Smooth muscles of its wall showed disruption and degeneration of their fibers.

These changes in the wall and luminal areas of both umbilical arteries and vein may be partially explained by the fact that throughout the last 2 weeks of pregnancy, the cord vessels show increasing responsiveness to mechanical irritation. Furthermore, these vessels are exquisitely sensitive to various endocrine mediators, such as serotonin, angiotensin, prostaglandins and oxytocin. This fact was also reported by Blanco et al., ${ }^{[33]}$ who said that complete explanation for these findings is difficult to be given; however, some facts may be taken into consideration. Moreover, smooth muscle cells are influenced in paracrine loops by vasodilator substances produced within the neighboring endothelial cells, like prostaglandins and nitric oxide and by the autocrine stimuli of atrial natriuretic peptide and other substances.
In the present study, examination of sections stained with Mallory trichrome of diabetic samples showed that there were disruption and decreased amount of collagen fibers, with disorientation of their normal arrangement in intima and in-between SMC of media of umbilical blood vessels. This result agreed with Charkraborty et al., ${ }^{[26]}$ who stated that there was alteration in the pattern of distribution and degeneration of collagen fibers in GDM. Similarly, Koskinen et al., ${ }^{[27]}$ reported that maternal diabetes induces rupture of the collagen fibers and edema of human umbilical cord of newborn infants. Also, examination of light microscopic sections stained with orcein showed that the umbilical arteries were characterized by the presence of elastic fibers in the intima with lack of internal elastic lamina while media showed few elastic fibers in between muscle cells. The umbilical vein showed prominent interrupted internal elastic lamina that not continuous all through the intimal layer with few elastic fibers in media. Spurway et al., ${ }^{[34]}$ mentioned that the walls of the UC artery of control samples showed lack of an internal and external elastic lamina and the adventitia was replaced by mucous connective tissue.

In diabetic group of the current study, the amount of elastic fibers was decreased in the walls of umbilical blood vessels with loss of its orientation. Deterioration of elastic tissue in diabetes act to provoke calcification as a response which may lead to decrease blood flow and spontaneous fetal death. This result agreed with Donald, ${ }^{[35]}$ who said that elastin formation appears to be slowed by hyperglycemia.

According to the current results, diabetic pregnancies showed more arterial and venous lesions of umbilical cord vessels and significant changes of their wall thickness and lumen diameters, suggesting that vascular alterations must be considered as concurrent causes and/or consequences in the broad spectrum of high-risk pregnancy. Leach, ${ }^{[36]}$ mentioned that vascular alterations in umbilical vessels may have been developed also in other fetal vascular beds when exposed to hyperglycemia.

\section{CONFLICT OF INTEREST}

There are no conflict of interest.

\section{REFERENCES}

1. Rohinidevi M, Jeyasingh T, Vimala V.: Morphological study of umbilical cord and its embryological significance. Int J Anat Res, Vol (2016) 4(1):1806-09.

2. Moore K.L, Persaud TVN, Torchia M.G. (2016): The developing human, clinically oriented embryology, 10th edition. Elsevier - united states, (2016) chapter $7 ; 124: 126$

3. Rafah H. Lateef: Histological study of umbilical cord at different stages of gestation Egypt. J. Exp. Biol. (Zool.), (2013) 9(1): 75 - 78.

4. Sadler, T W (Thomas W); Langman, Jan. Medical embryology.12th ed. / T.W. Sadler. Philadelphia: Wolters Kluwer Health/Lippincott Williams and Wilkins, (2012). pp. 103 -110. 
5. Luis Manuel Barrios Arpi: Histology of Umbilical Cord in Mammals, Histology, Thomas Heinbockel and Vonnie D.C. Shields, IntechOpen, November $5^{\text {th }}(2018)$.

6. Shoback, edited by David G, Gardner, Dolores.: Greenspan's basic and clinical endocrinology, $9^{\text {th }} \mathrm{ed}$. New york: McGraw-Hill Medical. Pp. chapter17. (2011) ISBN 0-07-162243-8.

7. Manuel Va'zquez Blanco, Hilda Ruda Vega, Roberto A. Guerri-Guttenber, Rodolfo Giuliano, Daniel R. Grana, Francisco Azzato, Jose' Milei: Histopathology and histomorphometry of umbilical cord blood vessels. Findings in normal and high risk pregnancies Artery Research, (2011).

8. EL SAWY, N. A.; IQBAL, M. S. and ALKUSHI, A. G.: Histomorphological study of placenta in gestational diabetes mellitus. Int. J. Morphol., (2018) 36(2): $\quad$ 687-692.

9. Denice S. Feig, FRCPC, Howard Berger, Lois Donovan, FRCPC, Ariane Godbout, FRCPC, Tina Kader, FRCPC, Erin Keely, FRCPC, Rema Sanghera: Diabetes and Pregnancy, Can J Diabetes (2018)42 S255-S282.

10. Joshy G, Simmons D.: Epidemiology of diabetes in New Zealand: revisittoa changing landscape. New Zealand Medical Journal (2006); 119. 2:7.

11. Bortolon, L.N.M., Triz, L. de P.L., Faustino, B. de S., de Sá, L.B.C., Rocha, D.R.T.W. and Arbex, A.K.: Gestational Diabetes Mellitus: New Diagnostic criteria. Open Journal of Endocrine and Metabolic Diseases; (2016) 6. 13:19.

12. Collier A, Abraham EC, Armstrong J, Godwin J, Monteath K, Lindsay R: Reported prevalence of gestational diabetes in Scotland: the relationship with obesity, age, socioeconomic status, smoking and macrosomia, and how many are we missing? J Diabetes Investig; (2017) 8 (2):161- 67.

13. Song C, Lyu Y, Li C, et al: long term risk of diabetes in women at varying durations after gestational diabetes: Systematic review and meta-analysis with more than 2 million women. Obe Rev; (2018) 19(3): 421-29.

14. Kampmann, U., et al.: Gestational Diabetes: A Clinical Update. World Journal of Diabetes; (2015) 6. 1065:1072.

15. Alfadhli, E M.: Gestational Diabetes Mellitus. Saudi Medical Journal, (2015) 36, 399-406.

16. Feig DS, Razzaq A, Sykora K, et al.: Trends in deliveries, prenatal care, and obstetrical complications in women with pre-gestational diabetes: a population based study in Ontario, Canada, 1996-2001, Diabetes Care; (2006) 29. 232:235.
17. Karen L, Whalen, JamesR, Taylor:Gestational diabeties mellitus. PSAP BOOK1 Endocrinology/ Nephrology: (2017)7:22.

18. Rafiqul Alam,. Abdul Momen, Anjuman Ara Sultana, SM Nurul Hassan Gross and Histomorphologic Study of the Umbilical Cord in Pre-gestational Diabetes Mellitus and Gestational Diabetes Mellitus Bangladesh Journal of Anatomy January ( 2014), Vol. 12, No. 1 pp. 25-29.

19. Bancroft, J.D. and Gamble, M.: Theory and Practice of Histological Techniques, 8th ed. Churchill livingstone, Edinburugh and London; (2008) 92:101. 9.

20. Singh, D.R.: Principles and Techniques in Histology Microscopy and Photomicrography,1st ed. CBC. New Delhi, Bangalore (India) (2003); 83:84.

21. Robinsons, D.G., Ehlers, U., Herken, U.E., Herrmann, B., Meyer, F. and Schurmann, F.W.: Methods for preparation for electron microscopy. An introdumbilical cordtion for the biochemical science. Muhlethaler K. Springer-verlag, Berlin, Heidelberg, New York- London- Paris- Tokyo. ISBN (1987).

22. Mustafa HN, El Awdan SA, Hegazy GA, Jaleel GAA.: Prophylactic role of coenzyme Q10 and Cynara scolymus L on doxorubicin-induced toxicity in rats: Biochemical and immunohistochemical study. Indian J Pharmacol. (2015);47(6):649.

23. Mould, R.F.: Introdumbilical cordtory medical statistics. 2nd ed, Adam Hilger, Bristol and Philadelphia, (1989) p 17, 22.

24. Predanic M.: Sonographic assessment of the umbilical cord. Donald School J Ultrasound Obstet Gynecol; (2009)5(2). 48:57.

25. EI-Nefiawy N.E.: Development of Human Umbilical Vessels in the Second Trimester of Pregnancy: Histological, Immunohistochemical and Morphometric Study. EJH (2017)vol 40 issue 2.

26. Chakraborty SK, Banu LA.: microscopic impacts of gestational diabetes mellitus on the umbilical cord. Mymensingh Med J; (2013)755- 60.

27. Koskinen A, Kääpä P, Soukka H.: The effects of maternal hyperglycemia on human umbilical vascular gene expression and neonatal rat lung development. Department of Pediatrics, Research Centre of Applied and Preventive Cardiovascular Medicine (CAPC), University of Turku, Turku, Finland, (2014) pp. 16. 17.

28. Di Fulvo P, Pandolfi A, Formoso G, Di Silvester S, Di Tomo P.: Feature of endothelial dysfunction in umbilical cord vessels of women with gestational diabetes. Nutr Metab Cardiovasc Dis; (2014)24(12): 1337-45. 
29. Vas P R J, Edmonds ME.: Early recognition of diabetic peripheral neuropathy and the need for one-stop microvascular assessment. Lancet Diab Endocrinol. (2016) (16) 30063-8.

30. Salem ME, Ismael A-AA, Salem A, Salem T.: Ultrastrumbilical cordtural changes in peripheral arteries and nerves in diabetic ischemic lower limbs, by electron microscope. Alexandria Journal of Medicine 53 (2017) 373-379.

31. Alam R, Momen A, Sultana AA, Hassan N.: Gross and Histomorphologic Study of the Umbilical Cord in Pre-gestational Diabetes Mellitus and Gestational Diabetes Mellitus . Bangladesh Journal of Anatomy January, (2014) Vol. 12, No. 1 pp. 25-29.

32. Sarikabadayi YU, Aydemir O, Kanmaz G, Aydemir C, Oguz SS, Erdeve O, Eyi EG, Zergeroglu S, Dilmen U. : Umbilical artery intima-media and wall thickness in infants of diabetic mothers. Neonatology (2012) 102(2):157-162.

33. Blanco MV et al.: Histopathology and histomorphometry of umbilical cord blood vessels. Finding in normal and high risk pregnancies, Artery Research. (2011).02.001.

34. Spurway J, Logan P, Pak S.: The development, strumbilical cordture and blood flow within the umbilical cord with particular reference to the venous system. AJUM August (2012) 15: 99.

35. Donald E.: Development of vascular complications In diabetes. Vascular Medicine; (1997) 2. 132:142.

36. Leach L.: Placental vascular dysfunction in diabetic pregnancies: intimations of fetal cardiovascular disease? Microcirculation (2011) 18(4):263-269. 
الملخص العزبى

\section{دراسة هستولوجيه لتركيب الحبل السري البشرى فى \\ الحمل المصحوب بمرض البول السكرى}

\section{منى عبد الرحمن سالم، إيمان سعيد محمود، هبة يوسف اليماني

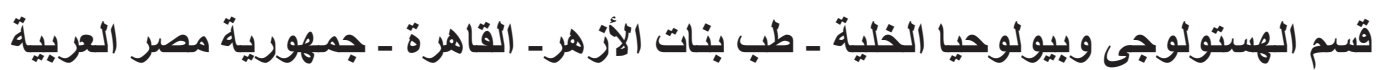

خلفية البحث: الحبل السري هو الحبل الذي بربط الجنين بالمشيمة. وداء البول السكري المصاحب للحمل هو احد الامر اض شائعة الحدوث و غالبا ما تسبب مضاعفات للجنين و الأم. الهرف من البحث: در اسة التغير ات النسيجية في تركيب الحبل السري المأخوذة من مواليد لسيدات مصابة بداء الحمل المصحوب بداء البول السكري.

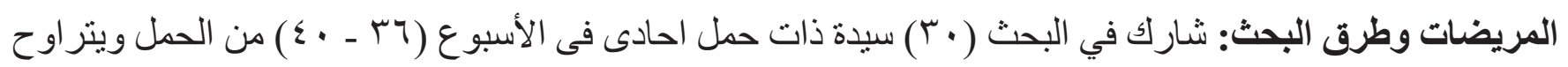
اعمار هن بين (Y0 ـ م ب) سنه في قسم التوليد وأمر اض النساء بمستشفى الزهر اء الجامعي بعد الولادة الطبيعية أو القيصرية مباشرة وقسمت إلى مجمو عنين: ( مجمو عة ضابطه): وتشمل 10 سيدة ذات حمل طبيعي. (مجمو عة مصابه بداء البول السكري المصاحب للحمل): وتثمل 1 سيدة، وتم الحصول على مو افقه كتابية من الأمهات المشاركات في البحث بعد الولادة مباشرة تم جمع عينات الحبل السري من الجهه المجاورة للطفل (قرب سرة الطفل) ونم تجهيزها للفحص باستخدام المجهر الضوئى بعد صباغة العينات بصبغة الهيماتوكسيلين والايوسين للتركيب العام وبصبغة المالورى الثثلاثية لإظهار ألباف الكو لاجين وصبغة الأورسين لإظهار الألياف المرنة. كما تم تحضير عينات للفحص لئس المجهري باستخدام الميكروسكوب الإلكتروني وتم صبغها بأسيتات اليور انيل يليها سيتر ات الرصاص. وكذللك أجريت دراسات مورفومترية لقياس مساحة الكو لاجين في كل من جدر الثرايين والوريد، كذلك قياس سمك جدار الثريان

$$
\text { و الوريد وقطر تجويف الوريد. وقُيمت النتائج إحصائيا. }
$$

النتائج: أظهر الفحص المجهري باستخدام المجهر الضوئى لأجز اء الحبل السري من المجمو عة الضابطة انه يتكون من شريانين ووريد ونسيج ضام يعرف باسم وارتون جيلى ويحيط به الغشاء الامنيوسي، ويتكون وارتون جيلى من الخلايا الليفية و النسيج الضام المخاطي كما بينت الثرايين تجويف نجمي الثكل وتتكون من طبقتين بينما بين الوريد تجويف أوسع و جدار اقل سمكا من الثريان ويتكون من طبقتين أيضا. و أظهرت العينات المصابة بداء البول السكري اضطر اب وقلة ألياف الكو لاجين فى الوارتون جيلي بشكل ملحوظ وأصبحت متباعدة بمساحات غير منتظمة شبيه بخلايا العسل. و ازداد سمك جدار الشريان بشكل ملحوظ وقل قطر تجويفه في حين اتسع قطر تجويف الوريد وأصبح جداره اقل سمكا. كما لوحظ تآكل النسيج الطلائى للأو عيه الدمويه مع فصل ألياف العضلات الملساء وخروج الدم خارج تجويف الاو عيه الدمويه. كما انخفضت كمية ألالياف الكولاجينية والألياف المرنة في جدار الأوعية الدمويه لعينات الحبل السري 
المصابه بداء البول السكرى مع تباين توزيعها عن الطبيعي. وقد أكد الفحص بالميكروسكوب الإلكتروني التغييرات التي تمت رؤيتها في الفحص بالميكروسكوب الضوئي كما أظهر زيادة محتوى الجليكوجين من العضلات الملساء فى بـ العينات المصابه بداء البول السكري إذا ما قورنت بعينات المجمو عه الضابطه. وكانت النتائج ذات دلاله احصائية. الاستتتاج: اثبت البحث ان داء البول السكري له تاثثير ات ضارة عديدة علي التركيب الدقيق للحبل السري و التي قد نؤثر علي حياة وصحة الجنين المولود. 